\title{
Theophylline protects against diabetes in BB rats and potentiates cyclosporine protection
}

\author{
A. Rabinovitch and W.L.Sumoski \\ Departments of Medicine and Immunology, University of Alberta, Edmonton, Alberta, Canada
}

\begin{abstract}
Summary. Type 1 (insulin-dependent) diabetes mellitus results from autoimmune cell-mediated destruction of pancreatic islet Beta cells. Since theophylline has suppressive effects on immune responses, we sought to determine if this agent might protect against destruction of islet Beta cells in diabetes-prone BB rats. Diabetes-prone rats were divided into four groups and treated, from age 30 to 125 days, with: (a) no treatment (control), (b) theophylline $2 \mathrm{mg} \cdot \mathrm{ml}^{-1}$ added to the drinking water, (c) cyclosporine $5 \mathrm{mg} \cdot \mathrm{kg}^{-1} \cdot \mathrm{day}^{-1} \mathrm{ad}-$ ministered by gavage, and (d) theophylline plus cyclosporine. By age 125 days, diabetes (glucosuria and serum glucose $\left.>11 \mathrm{mmol} \cdot \mathrm{l}^{-1}\right)$ had appeared in 15 of $17(88 \%)$ of
\end{abstract}

control rats, 10 of $18(56 \%)$ on theophylline, 6 of $17(35 \%)$ on cyclosporine, and 1 of $17(6 \%)$ on theophylline plus cyclosporine. Protection against diabetes by theophylline and cyclosporine was associated with preservation of pancreatic Beta cell mass (insulin content). The protective effects of combination therapy with theophylline and cyclosporine were achieved at very low serum concentrations of cyclosporine. These findings suggest that theophylline may be a useful adjunct in the immunosuppressive therapy of Type 1 diabetes.

Key words: BB rat, insulitis, cyclosporine, theophylline.
There is now abundant evidence that Type 1 (insulin-dependent) diabetes mellitus results from destruction of pancreatic islet Beta cells by mononuclear cells of the immune system. The strongest evidence has been obtained in animal models with spontaneous diabetes, including the Bio-Breeding (BB) rat. A variety of immune-suppression procedures have been reported to prevent and/or cure diabetes in the diabetes-prone (DP) BB rat [1]. These include neonatal thymectomy, total lymphoid irradiation, anti-lymphocyte globulin, monoclonal antibodies to $T$ lymphocytes and/or NK cells, and cyclosporine (CsA).

Another approach to suppressing immune reactions involves increasing adenosine $-3^{\prime}, 5^{\prime}$-monophosphate (cAMP) levels in lymphocytes [2]. Theophylline, a phosphodiesterase inhibitor effective in elevating cellular levels of cAMP, has been reported to prolong pancreatic allografts in rats [3], and to protect against diabetes induced by multiple low-dose streptozotocin in rats [4]. Also, theophylline has been reported to increase the frequency of clinical remission in a study of 18 recent-onset Type 1 diabetic subjects [5].

The purpose of the present study was to assess theophylline as a possible protective agent against diabetes in the $\mathrm{BB}$ rat, and to determine whether theophylline could potentiate the protective effects of CsA.

\section{Materials and methods}

\section{Animals}

Diabetes-prone (DP) BB rats were obtained from the National Institutes of Health contract colony at the University of Massachussetts Medical School, Worcester, Mass., USA (Dr. A.A.Like). DP rats have been sib-mated for over 35 generations and develop spontaneous Type 1 diabetes between $\sim 60$ and 120 days of age (70-90\% incidence). Diabetes-resistant (DR) BB rats have been inbred for resistance to diabetes ( $<1 \%$ incidence).

\section{Experimental groups}

DP rats (26 males, 43 females) from 101 were divided randomly into four groups at age $28-32$ days. The first group ( 7 males, 10 females) received no treatment (controls); the second group ( 7 males, 11 females) received theophylline $\left(2 \mathrm{mg} \cdot \mathrm{ml}^{-1}\right)$ added to the drinking water and made up fresh three times a week; the third group (6 males, 11 females) received CsA $\left(5 \mathrm{mg} \cdot \mathrm{kg}^{-1}\right)$ dissolved in olive oil $\left(2 \mathrm{mg} \cdot \mathrm{ml}^{-1}\right)$ and administered daily at 10.00 hours by gavage; the fourth group ( 6 males, 11 females) received both theophylline and CsA in the same doses as for groups 2 and 3 respectively. CsA was generously supplied by Sandoz Research Institute (East Hanover, NJ, USA). 


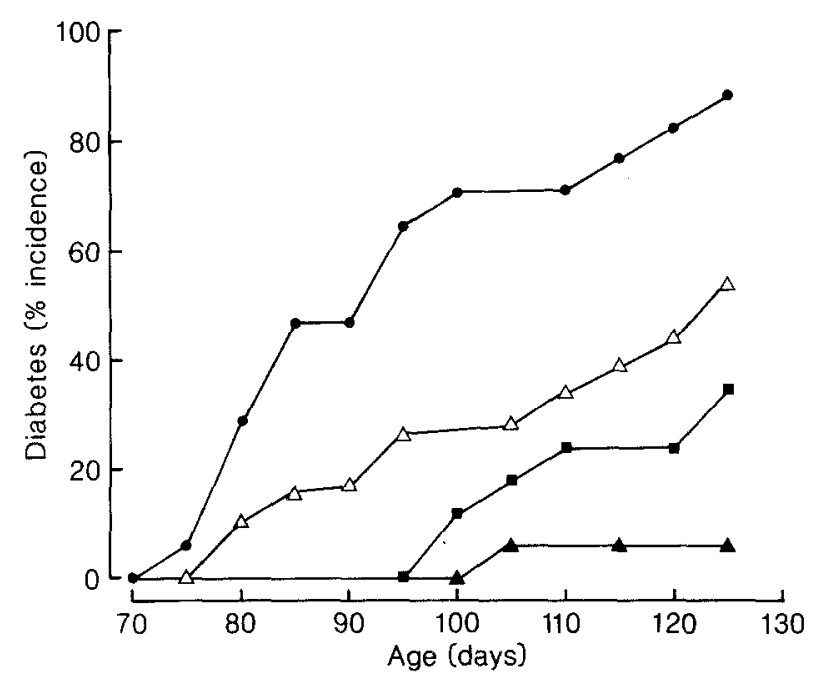

Fig. 1. Time course for appearance of diabetes in diabetes-prone BB rats receiving no treatment $(\bullet, n=17)$; and treated from age 30 to 125 days with $2 \mathrm{mg} \cdot \mathrm{ml}^{-1}$ theophylline $(\triangle, n=18)$ added to the drinking water, $5 \mathrm{mg} \cdot \mathrm{kg}^{-1} \cdot$ day $^{-1}$ cyclosporine $(\mathbf{\square}, n=17)$ given by gavage in olive oil, and theophylline plus cyclosporine in the same doses $(\mathbf{\Lambda}, n=17)$

\section{Assays}

The rats were monitored daily for glucosuria, from age 60 days. Diabetes was defined as the presence of $4+$ glucosuria (Testape, Lilly Research Laboratories, Indianapolis, Ind., USA) and a tail vein plasma glucose $\geq 11 \mathrm{mmol} \cdot 1^{-1}$, measured on a glucose analyser 2 (Beckman Instruments, Inc., Fullerton, Calif., USA). The day of onset of diabetes was noted and the diabetic rats were anaesthetized with pentobarbital, $50 \mathrm{mg} \cdot \mathrm{kg}^{-1}$ body weight. The pancreas was excised, minced with fine scissors, sonicated, and incubated at $4^{\circ} \mathrm{C}$ for $16 \mathrm{~h}$ in acid ethanol ( $75 \%$ ethanol, $1.5 \% 12 \mathrm{~mol} \cdot 1^{-1} \mathrm{HCl}$, and $23.5 \%$ $\mathrm{H}_{2} \mathrm{O}$ ) to extract insulin from the cells for determination of pancreatic insulin content by radioimmunoassay, using a kit for rat insulin (Pharmacia, Uppsala, Sweden). Also, at ages 60 and 90 days, blood was collected from tail veins of surviving non-diabetic rats for measurement of serum theophylline, and for serum CsA (24 hours after administration) using a radioimmunoassay kit (Sandoz Research Institute, East Hanover, NJ, USA). The study was terminated at 125 days of age. Survivors (without diabetes) were anaesthetized, bled for serum theophylline and CsA assays, and pancreata were excised for determination of insulin contents.

\section{Data analysis}

Statistical analyses of effects of treatment on diabetes incidence were carried out with the Chi Square test, using $2 \times 2$ tables, $\mathrm{df}=1$. Other data are presented as means \pm SEM and statistical significances were analysed by one-way analysis of variance.

\section{Results}

Diabetes first appeared in control DP rats at age 75 days, and 15 of $17(88 \%)$ of the DP rats had become diabetic by 125 days of age (Fig. 1). The incidence of diabetes was decreased to $56 \%$ (10 of 18$)$ in DP rats receiving theophylline $(p<0.05), 35 \%$ (6 of 17$)$ in DP rats receiving CsA $(p<0.001)$, and $6 \%$ ( 1 of 17$)$ in DP rats receiving theophylline and CsA $(p<0.001)$. The incidence of diabetes in the group treated with theophylline and CsA $(6 \%)$ was significantly less than in the groups treated either with theophylline alone $(56 \%, p<0.002)$ or with CsA alone $(35 \%, p<0.05)$.

Administration of theophylline in a fixed dose (2 $\mathrm{mg} \cdot \mathrm{ml}^{-1}$ ) in the drinking water produced serum theophylline levels which decreased with increasing age (and body weight) of the DP rats. Serum theophylline concentrations $\left(\mu \mathrm{g} \cdot \mathrm{ml}^{-1}\right)$ in DP rats receiving theophylline alone were $61.8 \pm 3.0(n=18)$ at 60 days, $45.3 \pm 3.6(n=13)$ at 90 days, and $24.5 \pm 2.5(n=8)$ at 125 days; and in DP rats receiving theophylline plus CsA, serum theophylline concentrations were $29.3 \pm 3.4(n=17)$ at 60 days, $26.5 \pm 3.4$ $(n=17)$ at 90 days, and $12.2 \pm 1.8(n=16)$ at 125 days. Thus, serum theophylline levels in DP rats receiving theophylline plus CsA were only half the values in DP rats receiving theophylline alone, at corresponding ages. Nevertheless, the combination of theophylline and CsA provided greater protection against diabetes $(6 \%$ incidence) than that observed with theophylline alone ( $56 \%$ incidence). Also, the greater protection against diabetes provided by the combination of theophylline and CsA ( $6 \%$ incidence) than by $\mathrm{CsA}$ alone ( $35 \%$ incidence) was not due to any effect of theophylline on serum CsA levels. Thus, serum CsA levels $\left(\mathrm{ng} \cdot \mathrm{ml}^{-1}\right)$ were not significantly different in rats receiving CsA alone: $23.3 \pm 2.3(n=17)$ at 60 days, $24.2 \pm 3.4(n=17)$ at 90 days, and $30.1 \pm 5.3$ $(n=11)$ at 125 days, and rats receiving theophylline plus CsA: $25.9 \pm 1.5(n=17)$ at 60 days, $24.0 \pm 4.4(n=17)$ at 90 days, and $27.6 \pm 4.5(n=16)$ at 125 days.

Protection against diabetes, assessed by detection of glucosuria, was further confirmed by measurement of serum glucose and pancreatic insulin in the different treatment groups (Table 1). All non-glucosuric DP rats had serum glucoses $<6.7 \mathrm{mmol} \cdot 1^{-1}$. Also, mean serum glucose values in the non-glucosuric DP rats of the different treatment groups were similar and not significantly different from the mean serum glucose value in the DR group of rats. All glucosuric DP rats had serum glucoses $>11 \mathrm{mmol} \cdot 1^{-1}$, and pancreatic insulin contents in these

Table 1. Serum glucose concentrations and pancreatic insulin contents in $\mathrm{BB}$ rats

\begin{tabular}{lllrcr}
\hline $\begin{array}{l}\text { BB } \\
\text { rat }\end{array}$ & Treatment & $\begin{array}{l}\text { Glucos- } \\
\text { uria }\end{array}$ & $n$ & $\begin{array}{l}\text { Serum } \\
\text { glucose } \\
\left(\mathrm{mmol} \cdot \mathrm{l}^{-1}\right)\end{array}$ & $\begin{array}{l}\text { Pancreatic } \\
\text { insulin } \\
\left(\mathrm{ng} \cdot \mathrm{mg}^{-1}\right)\end{array}$ \\
\hline DP & 0 & + & 15 & $22.8 \pm 0.9^{\mathrm{a}}$ & $0.7 \pm 0.2^{\mathrm{a}}$ \\
DP & Theophylline & + & 10 & $19.4 \pm 1.3^{\mathrm{a}}$ & $1.1 \pm 0.4^{\mathrm{a}}$ \\
& & - & 8 & $5.7 \pm 0.3$ & $37.7 \pm 4.9$ \\
DP & CsA & + & 6 & $18.4 \pm 1.0^{\mathrm{a}}$ & $1.1 \pm 0.5^{\mathrm{a}}$ \\
& & - & 11 & $6.3 \pm 0.3$ & $36.3 \pm 4.0$ \\
DP & Theophyl- & + & 1 & 24.9 & 1.4 \\
& line + CsA & - & 16 & $5.9 \pm 0.2$ & $36.7 \pm 2.4$ \\
DR & 0 & - & 12 & $5.4 \pm 0.3$ & $38.4 \pm 4.5$ \\
\hline
\end{tabular}

Diabetes-prone (DP) BB rats were treated from age 30 to 125 days with $2 \mathrm{mg} \cdot \mathrm{ml}^{-1}$ theophylline added to the drinking water, $5 \mathrm{mg}$. $\mathrm{kg}^{-1} \cdot$ day $^{-1}$ cyclosporine (CsA) given by gavage in olive oil, or theophylline + CsA. Mean values \pm SEM for serum glucose and pancreatic insulin are shown for the numbers of animals $(n)$ that were glucosuric $(+)$ or not $(-)$ by 125 days.

${ }^{a} p<0.001$ and ${ }^{b} p<0.05$ vs values in diabetes resistant (DR) BB rats 
diabetic animals were significantly decreased (>95\%) below the mean pancreatic insulin content in the DR group of rats. Pancreatic insulin contents in the DP rats protected from diabetes by theophylline, CsA and theophylline plus CsA were similar to the value in DR rats. By contrast, pancreatic insulin content in non-treated DP control rats that remained non-glucosuric was significantly decreased $(\sim 40 \%)$ compared to the value in DR rats.

\section{Discussion}

In the present study, we have shown that theophylline can significantly decrease the incidence of diabetes in BB rats. Also, addition of theophylline to a dose of CsA $\left(5 \mathrm{mg} \cdot \mathrm{kg}^{-1} \cdot \mathrm{day}^{-1}\right)$ which provided only partial protection against diabetes, almost totally prevented the appearance of the disease. These additive protective effects of theophylline and CsA were achieved at serum concentrations of CsA $\left(25-30 \mathrm{ng} \cdot \mathrm{ml}^{-1}\right)$ below levels considered necessary to suppress immunopathological responses, and at serum concentrations of theophylline (10-30 $\left.\mu \mathrm{g} \cdot \mathrm{ml}^{-1}\right)$ in the therapeutic range for the treatment of pulmonary diseases with bronchospasm.

The protective effects of theophylline and CsA against diabetes were associated with preservation of pancreatic islet Beta cell mass. Thus, recovery of pancreatic insulin in non-glucosuric DP rats treated with theophylline and/or CsA was the same as in DR rats, and greater than in nonglucosuric DP rats receiving no treatment. Preservation of islet Beta cell mass by CsA and/or theophylline suggests that a destructive insulitis was prevented by these agents. CsA is known to prevent insulitis in BB rats, including the initial entry of activated macrophages [6]. However, it remains to be determined whether theophylline protected Beta cells by preventing infiltration of mononuclear cells, by inhibiting the cytotoxicity of these cells, and/or by direct protective effects on the Beta cells themselves.

Absence of a regulatory or suppressor subset of T lymphocytes has been implicated as a permissive cause of immune-mediated cytotoxic destruction of islet Beta cells in $\mathrm{BB}$ rats [7]. According to this concept, our results suggest that theophylline may substitute for regulatory $\mathrm{T}$ cells by preventing activation and/or action of cytotoxic effector cells. A large amount of literature exists describing the suppressive effects of elevated cAMP levels on differentiated functions of cells of the immune system, including inhibition of production of lymphokines [8], and inhibition of cytotoxicity of $\mathrm{T}$ cells [9] and natural killer cells
[10]. Further studies are in progress to determine the mechanism(s) of the protective effects of theophylline against autoimmune diabetes, and whether this can be related to elevation of cAMP levels in immunocompetent cells.

Acknowledgments. We gratefully acknowledge the technical assistance of Mr. J. Esposito, Mr. D. Dunaway-Piccioni, and Ms. M. Ashby, and the secretarial assistance of Ms. S. Schroeder. This work was supported by grants from the Alberta Heritage Foundation for Medical Research and the Muttart Diabetes Research and Training Centre.

\section{References}

1. Mordes JP, Desemone J, Rossini AA (1987) The BB rat. Diab Metab Rev 3:725-750

2. Coffey RG, Hadden JW (1985) Neurotransmitters, hormones, and cyclic nucleotides in lymphocyte regulation. Fed Proc 44: 112-117

3. Marni A, Ferrero ME, Rugarli C(1984) Effect of theophylline in experimental pancreas allotransplantation in rats. Transplant Proc 16: 799-801

4. Ferrero E, Marni A, Ferrero MC, Gaya G, Rugarli C(1985) The effect of cyclosporine and aminophylline on streptozotocin-induced diabetes in rats. Immunol Let 10: 183-187

5. Secchi A, Crosti F, Pastore MR, Pavoni D, Falqui L, Navone P, Pontiroli AE, Ciboddo GF, Rugarli C, Pozza G (1988) In vivo and in vitro effects of theophylline administration in recent onset, type 1, diabetic patients. Diab Nutr Metab 1: 113-118

6. Bone AJ, Walker R, Varey AM, Cooke A, Baird JD (1990) Effect of cyclosporin on pancreatic events and development of diabetes in BB/Edinburgh rats. Diabetes 39: 508-514

7. Greiner DL, Mordes JP, Handler ES, Angelillo M, Nakamura N, Rossini AA (1987) Depletion of RT6.1+ T lymphocytes induces diabetes in resistant Biobreeding/Worcester $(\mathrm{BB} / \mathrm{W})$ rats. J Exp Med 166: 461-475

8. Didier M, Aussel C, Ferua B, Fehlmann M (1987) Regulation of interleukin 2 synthesis by cAMP in human T cells. J Immunol 139: 1179-1184

9. Wolberg G, Zimmerman TP, Hiemstra K, Winston M, Chu LC (1975) Adenosine inhibition of lymphocyte-mediated cytolysis; possible role of cyclic AMP. Science 187: 957-959

10. Katz P, Zaytoun AM, Fauci AS (1982) Mechanisms of human cell mediated cytotoxicity. I. Modulation of natural killer cell activity by cyclic nucleotides. J Immunol 129: 287-296

Received: 4 February 1990

and in revised form: 23 April 1990

Dr. A. Rabinovitch

430 Heritage Medical Research Centre

University of Alberta

Edmonton, Alberta T6G 2S2

Canada 